\title{
Factor Analysis of the Determinants of Student Learning Behavior and its Influence on Student Learning Outcomes in Accounting Department of Padang Vocational High School (SMK) 3
}

\author{
Mudzalifa Yulias ${ }^{1}$, Idris ${ }^{2}$, Yulhendri ${ }^{1}$ \\ ${ }^{1}$ Universitas Negeri Padang, Padang, Indonesia, $\square$ syailend_ra@yahoo.com \\ ${ }^{2}$ Universitas Negeri Padang, Padang, Indonesia, $\square$ idris_unp@gmail.com \\ ${ }^{3}$ Universitas Negeri Padang, Padang, Indonesia, $\bowtie$ yulhendriunp@gmail.com
}

\begin{abstract}
This have purspore to determine the factors that influence students' learning behavior and the effect on the learning outcomes of accounting students at SMKN 3 Padang. In this study, 173 students of accounting department at SMKN 3 Padang were used. The variables used include personal factors, recommendation factors, and professional factors, learning behavior and student learning outcomes. The analysis used to prove the hypothesis is Path Analysis which is processed using SmartPLS 3.0. The test results show that personal factors, recommendation factors and professional factors influence learning behavior, while personal factors and recommendation factors do not affect learning outcomes. The results obtained also show that professional factors and learning behavior influence the learning outcomes of students of SMKN 3 Padang.
\end{abstract}

Keyword: Personal Factor, Recommendation Factor, Carrier Factor.

\section{Introduction}

One of the leading Vocational Schools in the city of Padang and located in the center of the city of Padang right on Sudirman street Number 11 Padang is the State Vocational High School 3 Padang. This vocational school is one of the most favorite vocational schools in the city of Padang in particular and West Sumatra in general. To attract the attention of the community, especially the guardians of students of SMKN 3 Padang, they offer expertise programs that can create competitive advantages for graduates of SMKN 3 Padang. In the last 2017/2018 school year, SMK 3 Padang offered four departments to the community namely Financial Accounting and Institutions (AKL), Online Business and Marketing (BDP), Computer and Network Engineering (TKJ) and Administration and Office Management (OTP).

Until now there are 1054 Padang 3 Vocational High School students active in the tenth to the twelfth grade. Among the four majors offered by SMK 3, the accounting department is one of the leading majors at Padang Vocational High School 3. Given that accounting is a part of the field of economics that is needed in the world of work. If observed the development of accounting students at SMK 3 Padang in the 2017/2018 school year ago the number of accounting students amounted to 87 students, while the Department of Automation and Office Management amounted to 91 students, Business and Online and Marketing majors had 32 students followed by majors Computer and network engineering with a total of 63 students.

The decline in the number of accounting students at SMK 3 Padang in the 2017/2018 school year is suspected to be considered difficult. Considering the full accounting subject with a count that requires students to be careful in working. Apart from the data obtained, it can be seen that the majority of students majoring in accounting are more interested in female gender students. In addition, students who choose accounting majors are believed to have high competence and high motivation in learning. Based on the data obtained from the school governance side, an overview is obtained of the average class scores of each department at Padang Vocational High School 3 shown in Table 2 below: 
Table 1 Average Odd and Even Semester Values Accounting Department of SMKN 3 Padang Academic Year 2017/2018

\begin{tabular}{|c|c|c|c|}
\hline \multirow{2}{*}{ Department / Class } & \multicolumn{3}{|c|}{$2017 / 2018$} \\
\hline & Odd & Even & Mean \\
\hline \multicolumn{4}{|l|}{ Class X } \\
\hline $\mathrm{AK}_{1}$ & 82.41 & 81.45 & 81.93 \\
\hline $\mathrm{AK}_{2}$ & 79,67 & 80.78 & 80.23 \\
\hline $\mathrm{AK}_{3}$ & 81,77 & 80.51 & 81.14 \\
\hline Mean & 81.28 & 80.91 & 81.10 \\
\hline \multicolumn{4}{|l|}{ Class XI } \\
\hline $\mathrm{AK}_{1}$ & 78.34 & 79.32 & 78.83 \\
\hline $\mathrm{AK}_{2}$ & 81.43 & 79.32 & 80.38 \\
\hline $\mathrm{AK}_{3}$ & 80.55 & 80.43 & 80.49 \\
\hline $\mathrm{AK}_{4}$ & 77.67 & 79.32 & 78.50 \\
\hline Mean & 79.50 & 79.60 & 79.55 \\
\hline \multicolumn{4}{|l|}{ Class XII } \\
\hline $\mathrm{AK}_{1}$ & 81.43 & 81.32 & 81.38 \\
\hline $\mathrm{AK}_{2}$ & 80.83 & 80.11 & 80.47 \\
\hline $\mathrm{AK}_{3}$ & 81.43 & 81.57 & 81.50 \\
\hline Mean & 81.23 & 81.00 & 81.12 \\
\hline
\end{tabular}

In table 2, it can be seen that the average score of Padang SMK 3 accounting department students is relatively diverse, if observed from the tenth grade the average semester grade score is 81.28 , in the odd semester of 2017/2018 the lowest average test score is owned by eleventh grade students namely 79.50. The same thing also happened in even semester 2017/2018, the average grade of twelfth grade was higher than other classes, namely 81 while the lowest average value was still in the eleventh class, namely 79.60. The fluctuation in the value of students who majored in accounting at SMK 3 Padang showed that each class had different abilities in understanding the accounting learning material provided by the teacher.

Different abilities of students in achieving achievement or learning outcomes are thought to occur because of differences in learning behavior possessed by accounting students at SMKN 3 Padang. Differences in learning behavior can be seen from the way each student does the learning activities. The better student learning behavior that can be observed from the regularity of learning activities outside the school environment in the form of repetition of material, doing assignments and exercises regularly, the recording process and the existence of group discussion activities. Increasingly positive and planned learning behavior will shape better learning outcomes.

According to Widowati and Surjawati (2014) student learning outcomes can be influenced by two factors namely internal factors and external factors. Basically, internal factors are a number of variables originating from within the student such as personal factors which include interests, talents, intellectual intelligence to motivation, while external factors are a number of variables originating from outside the student such as the existence of family support, recommendations from the teacher, peers to the community environment.

According to Luthan (2012), one of the internal factors that influence individual behavior, especially in carrying out activities or learning processes, is personal factors. Personality is a basic human nature from birth. Personal factors consist of talent, intelligence, emotional level, intelligence, interest and motivation. Personal factors become one of the supporting factors for the formation of learning behavior for students. When students feel the suitability of the chosen scientific field according to their talents, interests or desires within themselves, learning behavior will be positive.

A number of studies that discuss the influence of personal factors on student learning behavior have been carried out by Januar (2013) found that personal factors have a positive effect on student 
learning behavior in Semarang State University (UNNES) in 2013. The same results were also obtained in research conducted by Syarifudin (2011) who found that one of the internal factors that influence students' learning behavior is personal factors which include talent, intellectual intelligence and motivation possessed by students. Learning behavior will be better when the selection of subject areas of concetration is accompanied by interest, talent and the ability to learn and explore the areas of concentration chosen by students.

To strengthen the value of learning behavior that is formed in students, in addition to internal factors, learning behavior is also supported by external factors such as the support or recommendations from the teacher. Recommendations are a form of support from a teacher to students, especially in directing students to major in accounting. The recommendations given are of course based on a number of factors such as talents, or competencies that students have. For students the recommendations will make students more enthusiastic and try to provide better learning outcomes by improving their learning behavior.

The results of Yanuar's (2014) study found that encouragement or recommendations from teachers in schools had a positive effect on the learning behavior of students majoring in accounting at SMKN 1 Surakarta. Consistent findings were also obtained in the research of Syariffudin (2015) found that recommendation factors influence student learning behavior. Recommendations are protection or encouragement given by respected figures or respected students. Recommendations will create changes in student learning behavior. The respect that students have for individuals who provide recommendations encourages better learning behaviors, such as a strong awareness to spend time learning, doing assignments, and discussing to complete understanding in the academic process. Every student at SMKN 3 Padang is certain to have a long-term goal or orientation that will be fulfilled in the future, therefore one of the external factors that influence student learning behavior is a career factor. According to Gie (2009) a career is a broader one, because it has a term

\section{Methods}

\section{Object of research}

In this study, the object of the research was all grade $X$ students of SMK 3 Padang, having their address at Jalan Sudirman Number 11, Padang Barat District. Vocational 3 Padang was chosen because the vocational school was one of the best schools in the city of Padang.

\section{Population and Sample}

Population is the unity of attributes that work together to achieve one goal, in this study the population is all students of Padang $\mathrm{N}$ Vocational High School who choose the accounting department, which is 318 students as shown in Table 2 below:

Table 2 Details of the Number of Students in Class X Accounting Students SMK 3 Padang Academic Year 2017/2018

\begin{tabular}{lccc}
\hline \multirow{2}{*}{ Department } & \multicolumn{3}{c}{ Years 2017/18 } \\
\cline { 2 - 4 } & M & F & Jlh \\
\hline Class X & 27 & 71 & 98 \\
\hline Class XI & 31 & 55 & 86 \\
\hline Class XII & 23 & 97 & 120 \\
\hline Jumlah & 81 & 223 & 304 \\
\hline
\end{tabular}

Source: SMK 3 Padang (2018) 
In order to choose the sample size, the Slovin formula is used by using the formula formula as follows:

$$
\begin{aligned}
& n=\frac{N}{1+\left(N\left(e^{2}\right)\right)} \\
& n=\frac{304}{1+\left(304\left(0.05^{2}\right)\right)} \\
& n=172.72
\end{aligned}
$$

Based on calculations using the Slovin formula obtained a sample size of 173 students of SMKN 3 Padang. Given the sample size is above 150, the analysis tool used is SEM using AMOS 25.

\section{Operational Definition and Variable Measurement Endogenous variable}

Is the main variable that is influenced by exogenous variable. In this study the endogenous variables are learning outcomes.

\section{Study Result}

Learning outcomes show achievement in the form of progress or decline obtained by students in learning. In measuring learning outcomes, it is adopted the opinion explained by Meghann et al (2017) which states that learning outcomes can be observed from the values obtained by students which include midterm scores and final grades.

\section{Exsogenous Variable}

Is a variable that is thought to undergo changes, where the change will affect changes in exogenous variable. In general, the exogenous variables used are:

\section{Personal Factor}

Personal factors are a number of dimensions that originate in students, such as talent, creativity, and intellectual intelligence. In measuring personal factors, indicators are adopted from Widowati and Surjawati (2014) which include
a. Interest
b. The desire to be sincere,
c. Talent and experience in studying accounting subjects

\section{Recommendation Factors}

Recommendations are a number of information provided by a number of parties or individuals who are respected by students. In measuring recommendations observed from those who gave information. According to Widowati and Surjawati (2014) there are a number of parties who can provide recommendations, namely:
a. Parents
b. Friends of the same age
c. Teacher
d. Brother or the closest person

\section{Career Factors}

Career factors are a number of added values related to the continuation of the career that students have when deciding to take an accounting major. In measuring career factors, indicators are adopted from Surjowati (2014) which include:
a. Job prospects,
b. Future salary prospects
c. Prestige or prestige 


\section{Intervening Variable}

In general, interfening variables are defined as variables that influence the effects formed between exogenous variables on endogenous variables.

\section{Student Learning Behavior}

Student learning behavior addresses activities carried out repeatedly in carrying out learning activities specifically carried out by students majoring in accounting at SMKN 3 Padang. In measuring students' learning behavior, the indicators adopted by Nguyen and Nguyen (2010) are used, namely: providing free time to study, having notes on various materials studied, routinely doing assignments or exercises, discussions to strengthen understanding of the material that has been learned

\section{Analysis of Results and Discussion \\ Descriptive Respondents}

After all data and information have been collected, the stages of data processing can be carried out. Based on the process of identifying data from the questionnaires which are tabulated, the general descriptive of the respondents can be seen in Table 4 below:

Table 4 General Descriptive Respondents

\begin{tabular}{|c|c|c|}
\hline Information & Sum & Percentage \\
\hline \multicolumn{3}{|l|}{ Gender } \\
\hline Man & 38 & 21.97 \\
\hline Woman & 135 & 78.03 \\
\hline \multicolumn{3}{|l|}{ Umur } \\
\hline 15 years old & 54 & 31.21 \\
\hline 16 years old & 49 & 28.32 \\
\hline 17 years old & 68 & 39.31 \\
\hline 18 years old & 2 & 1.16 \\
\hline \multicolumn{3}{|l|}{ Parent Job } \\
\hline ABRI & 3 & 1.73 \\
\hline Lecture & 1 & 0.58 \\
\hline Teacher & 16 & 9.25 \\
\hline Government Employee & 79 & 45.66 \\
\hline Private Employee & 9 & 5.20 \\
\hline Police & 1 & 0.58 \\
\hline Entrepreneur & 64 & 36.99 \\
\hline \multicolumn{3}{|l|}{ Class } \\
\hline Class X AKL_1 & 19 & 10.98 \\
\hline Class X AKL_2 & 18 & 10.40 \\
\hline Class X AKL_3 & 19 & 10.98 \\
\hline Class XI AKL_1 & 18 & 10.40 \\
\hline Class X I AKL_2 & 18 & 10.40 \\
\hline Class X I AKL_3 & 13 & 7.51 \\
\hline Class XII AKL_1 & 17 & 9.83 \\
\hline Class X II AKL_2 & 17 & 9.83 \\
\hline Class X II AKL_3 & 17 & 9.83 \\
\hline Class X II AKL_4 & 17 & 9.83 \\
\hline Total & 173 & 100 \\
\hline
\end{tabular}

In accordance with the data tabulation process that has been carried out, it is known that most respondents with perepuan gender are 135 people or $78.30 \%$ of the total respondents while the 
remaining 38 people or $21.97 \%$ of the respondents are male. If observed based on the age level most of the respondents were 17 years old. This was recognized by 68 people or $39.31 \%$ of the total respondents, while the respondents with the lowest number were those aged 18 years, amounting to 2 people or $1.16 \%$ of the total respondents. In accordance with the data tabulation process it is also known that most students claim to have parents with permanent jobs as civil servants. The statement was recognized by 79 people or $45.66 \%$ of the total respondents, while respondents with the smallest number were those who had parents with permanent jobs as lecturers and members of the National Police, each of which had 1 person or only $0.58 \%$ of the total respondents. In the data tabulation process it is known that the total respondents used in this study amounted to 173 people consisting of 98 respondents who were students of class $\mathrm{X}$ majoring in accounting, 86 respondents who were students of class XI majoring in accounting while students with the highest number were those from class XII accounting majors totaling 120 respondents.

\section{Overall Confirmatory Factor Analysis (Overall CFA)}

In general, the overall confirmatory factor is seen in. Picture 1 is the result of the overall measurement model:

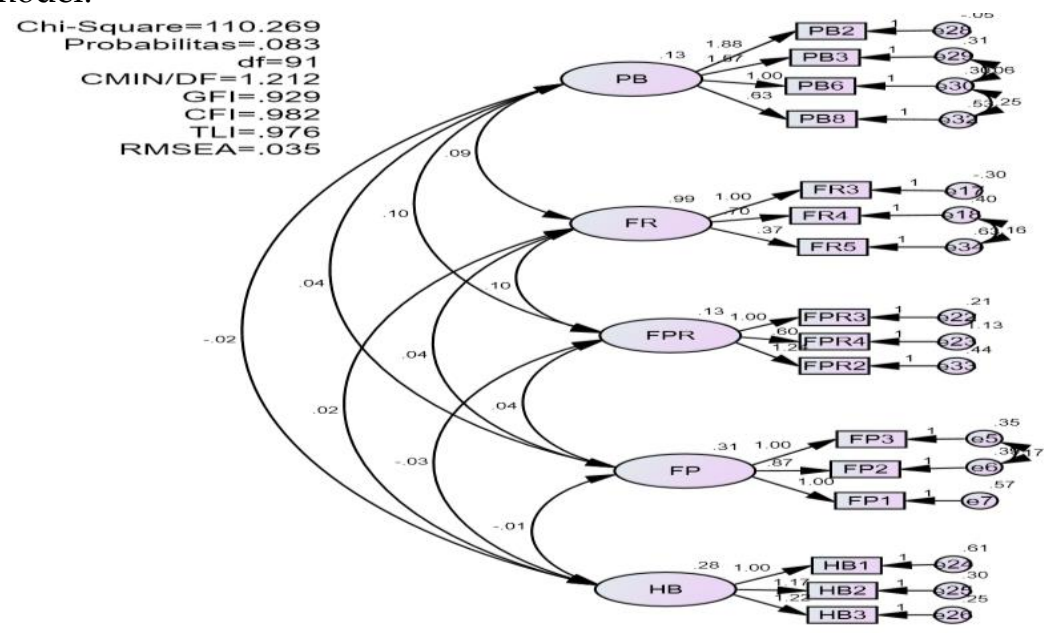

Figure 1 Overall Confirmatory Factor Analysis

To find out whether the Overall CFA model that was built statistically can be supported and in accordance with the specified fit model, the following is a comparison of the models built with the Goodness-of-Fit Indices requirements. The results of processing data related to Goodness-of-Fit from the overall CFA can be seen in Table 3 as follows:

Table 5 Goodness of Fit Indices dari Overall CFA

\begin{tabular}{lccc}
\hline $\begin{array}{c}\text { Goodness of Fit } \\
\text { Indices }\end{array}$ & Statistic & Cut Off Value & Interpretation \\
\hline Chi-square $\left(x^{2}\right)$ & 110.269 & Highest & Better fit \\
\hline Df & 91 & - & - \\
\hline Probability(pvalue) & 0,083 & $\geq 0,05$ & Better fit \\
\hline CMIN/DF & 1,212 & $\leq 2,00$ & Better fit \\
\hline GFI & 0,929 & $\geq 0,90$ & Better fit \\
\hline RMSEA & 0,035 & $\leq 0,08$ & Better fit \\
\hline TLI & 0,978 & $\geq 0,90$ & Better fit \\
\hline CFI & 0,982 & $\geq 0,90$ & Better fit \\
\hline Resources: Data Estimation AMOS 24 & &
\end{tabular}

From Table 5, it can be explained that some of the Goodness-of-Fit-Index constructs of overall CFA show results in accordance with the recommended cut-off value, namely CMIN / DF $1.212<2.00$, 
besides that the RMSEA value is $0.035<0.08$, TLI value $0.978>0.90$, and the CFI value is $0.982>0.90$. Thus the exogenous variables in the research model can be accepted as forming a fit model.

\section{Structural Modeling}

Structural modeling is a framework that shows the relationship between one exgogenous variable and endogenous variables, or a combination formed between exogenous variables and mediating variables that will affect endogenous variables. The model of the structural framework formed is shown in the picture below:

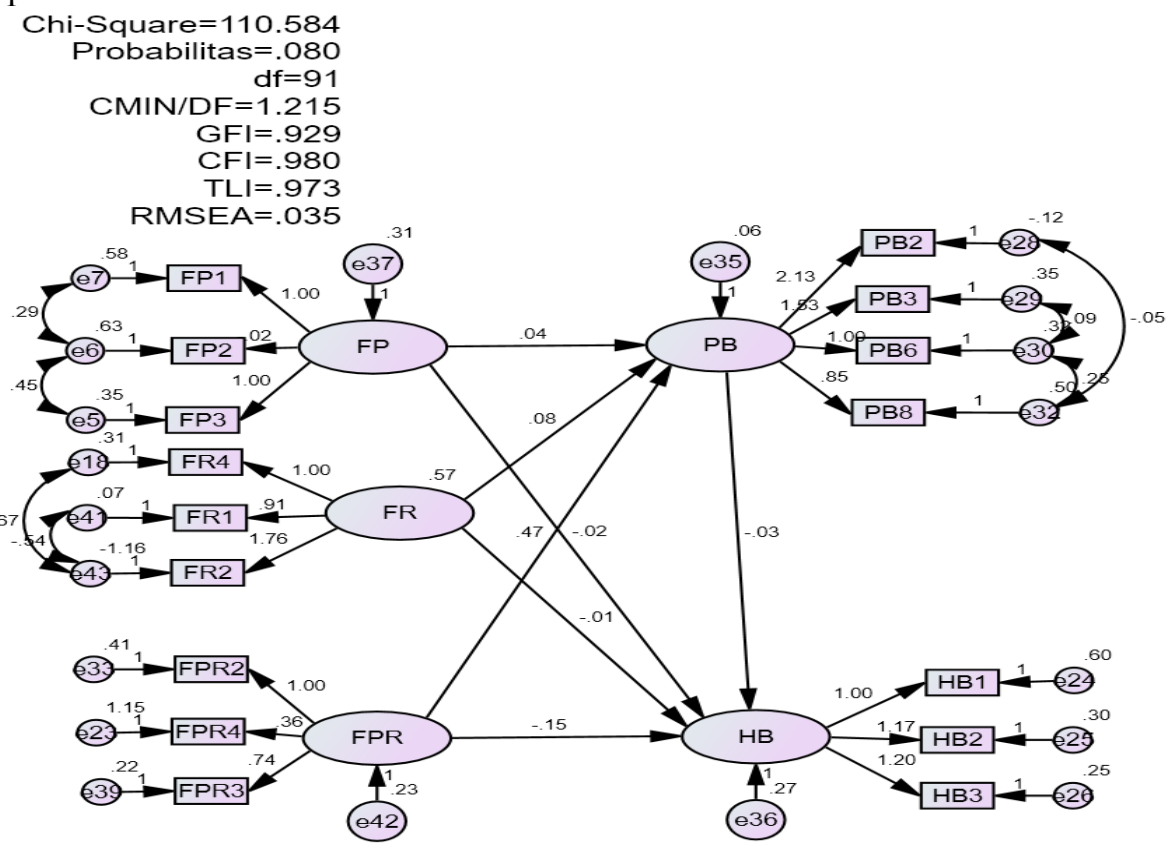

Figure 2 tructural Model

To ensure that the structural model formed is fit or must be modified, an analysis of the accuracy of the model is carried out. In accordance with the results of data processing that has been obtained, a summary is shown in Table 4 below:

Table 6 Goodness of Fit Indices Structural Model

\begin{tabular}{lccc}
\hline $\begin{array}{c}\text { Goodness of Fit } \\
\text { Indices }\end{array}$ & Statistic & Cut Off Value & Interpretation \\
\hline Chi-square $\left(x^{2}\right)$ & 101.584 & Highest & Better fit \\
\hline Df & 91 & - & - \\
\hline Probability(pvalue) & 0,080 & $\geq 0,05$ & Better fit \\
\hline CMIN/DF & 1,215 & $\leq 2,00$ & Better fit \\
\hline GFI & 0,929 & $\geq 0,90$ & Better fit \\
\hline RMSEA & 0,035 & $\leq 0,08$ & Better fit \\
\hline TLI & 0,973 & $\geq 0,90$ & Better fit \\
\hline CFI & 0,980 & $\geq 0,90$ & Better fit \\
\hline Resources: Data Estimation AMOS 24 & &
\end{tabular}

From Table 6 it can be explained that some Goodness-of-Fit-Index constructs of the model structure show results according to the recommended cut-off value, namely CMIN / DF $1.223<2.00$, RMSEA value $0.032<0.08$, TLI value $0.965>0.90$, and CFI value of $0.970>0.90$. Thus, exogenous variables in the research model can be accepted as forming a fit model. 


\section{Hypothesis testing}

After all the requirements are met, the stages of hypothesis testing can be done immediately. The processing is carried out using AMOS 24. To find out the magnitude of the direct effect formed between exgogenous variables on endogenous variables, a direct effect is carried out. Based on the results of the processing that has been done, the results obtained are shown in Table 5 below:

Table 7 The Results of Hypothesis Testing

\begin{tabular}{lccccc}
\hline \multicolumn{1}{c}{ Keterangan } & Estimate & C.R & Prob & Cut Off & Kesimpulan \\
\hline PB <--- FP & 0.036 & 0.996 & 0.319 & 0.05 & Not Significant \\
\hline PB <--- FR & 0.077 & 2.793 & 0.005 & 0.05 & Significant \\
\hline PB <--- FPR & 0.467 & 3.939 & 0.000 & 0.05 & Significant \\
\hline HB <--- FP & -0.022 & -0.280 & 0.779 & 0.05 & Not Significant \\
\hline HB <--- FPR & -0.148 & -0.739 & 0.460 & 0.05 & Not Significant \\
\hline HB <--- BB & -0.026 & -0.131 & 0.896 & 0.05 & Not Significant \\
\hline HB <--- FR & -0.008 & -0.225 & 0.822 & 0.05 & Not Significant \\
\hline Resources: Data Estimation AMOS 24 & & & &
\end{tabular}

According to the results of data processing that has been done, it can be seen that personal factors (FP) have a path coefficient (estimate) of 0.026 . The results obtained are strengthened by a probability value of 0.319. Stages of statistical testing are carried out using an error rate of 0.05 . The results obtained show that the probability value of 0.319 is greater than the error level of 0.05 , the decision is that Ho is accepted and $\mathrm{Ha}$ is rejected so it can be concluded that personal factors do not affect learning behavior (PB) in accounting students at SMKN 3 Padang.

The findings obtained at the stage of testing the first hypothesis are in line with the research conducted by Januar (2013) who found that personal factors did not influence students' learning behavior. The same results were also obtained by Henriyanto (2017) personal factors did not affect students' learning behavior. Personal factors in the form of awareness of students to realize their shortcomings can indeed foster positive learning behavior but not all students behave like that given the many other variables that can affect student learning behavior.

At the stage of testing the second hypothesis, it can be seen that the factor recommendation variable (FR) has a path coefficient of 0.077 . This value is proven statistically with a probability value of 0.005 . The stages of data processing are carried out using an error rate of 0.05 . Thus, the probability value of 0.005 is below the error rate of 0.05 , the decision is that Ho is rejected and Ha is accepted so that it can be concluded that the recommendation factor (FR) has a significant effect on learning behavior $(\mathrm{PB})$ in accounting students at SMKN 3 Padang.

The findings obtained at the stage of testing the second hypothesis are in line with the distribution of respondents' answers where it appears that the highest answer score is given by the respondent in responding to the statement that there is encouragement from parents in choosing accounting majors. The average score given is 3.77 with a TCR percentage of $75.38 \%$ while the lowest answer score given by respondents in assessing the statement of learning patterns developed by teachers at SMKN 3 Padang encourages high confidence in each student to choose the accounting department. The average score given is equal to 3.60 with a TCR percentage of $71.91 \%$. Overall, the five statements that support the recommendation factor variables produce an average score of 3.65 and the average TCR percentage of $72.99 \%$, so it can be concluded that the recommendations of respected people contribute relatively high in students to choose accounting majors at the State Vocational School. 3 Padang.

In accordance with the results of testing the second hypothesis, it was found that the recommendation factor had a positive and significant effect on students' learning behavior at SMKN 3 Padang. The results obtained show that the stronger the sense of reluctance or respect that students have for individuals or people who provide recommendations for majoring in accounting, the learning behavior that they show will be better. Encouragement from respected people such as parents, aunts, or uncles often creates self motivation for each student to prove themselves that the 
recommended things are not wrong but can provide better results in the future. As a result, students consciously routinely study, and actively seek out a number of references relating to accounting subjects. Consistency and regularity in carrying out the learning process will encourage increased learning outcomes that will be obtained by the students.

The findings obtained at the stage of testing the second hypothesis are in line with Yuniarti (2017) 's research stating that the recommendation factor of respected people will encourage better learning behavior in students. The same results were obtained in Nugroho's (2013) and Januar's (2013) study which found that recommendation factors in people who are influential in students such as parents, teachers or respected individuals will encourage improvement in student learning behavior especially in learning subjects accounting.

In accordance with the results of statistical tests that have been done, it is known that professional factor variables have a path coefficient value of 0.467 . The coefficient value is proven statistically with a probability of 0,000 . Data processing is done using an error rate of 0.05 . The results obtained show that the probability value of 0,000 is smaller than the error rate of 0.05 . So, the decision is Ho rejected and Ha accepted so that it can be concluded that professional factors influence student learning behavior.

This situation shows that the stronger the job opportunity or profession that can be obtained by accounting students in the future, the learning behavior of each student will continue to improve. The findings obtained at the stage of testing the third hypothesis are consistent with the results of research by Yuniarti (2017) who found that career or professional factors that can be achieved by students in the future are factors that encourage improvement in student behavior in learning. The same results were also obtained in the study conducted by Nugroho (2013) and Januar (2013) who found that career factors directly influence student learning behavior. The higher career or professional opportunities that students can achieve in the future further enhance the routines that students do in learning.

At the stage of testing the direct effect using the personal factor (FP) variable, the path coefficient value is negative at -0.022 . The value obtained is strengthened by a probability value of 0.779 . Data processing is done using an error rate of 0.05 . The results obtained show that the probability value of 0.779 is far above the error level of 0.05 , the decision is that Ho is accepted and Ha is rejected so that it can be concluded that personal factors (FP) have no significant effect on student learning outcomes in accounting at SMKN 3 Padang.

The findings obtained indicate that personal factors do not occur because students' awareness to add insight and knowledge through learning cannot always provide better learning outcomes. The results of Andika's research (2015) found that personal factors had a negative effect on student learning outcomes. The same findings were also obtained in the research of Andriani (2016) which states that personal factors are aware of the weaknesses and weaknesses in studying accounting subjects if they are not addressed by improving learning methods or learning methods so the learning outcomes tendencies obtained by students after evaluation through examinations will experience narrative.

Based on the results of testing the data it is known that the recommendation factor has a regression coefficient marked negative at -0.008 . The coefficient value obtained is strengthened by a probability of 0.822 . Data processing is carried out using an error rate of 0.05 . The results obtained show that the probability of 0.822 is large from the error rate of 0.05 so the decision is Ho accepted and Ha rejected so that it can be concluded that the recommendation factor (FR) does not significantly influence student learning outcomes (HS) accounting department at SMKN 3 Padang.

The results obtained are not in line with the hypothesis proposed. This situation occurs because recommendation factors do create awareness in students to really learn to provide good learning outcomes, but the consistency of learning does not guarantee students to get good grades. The findings obtained at the hypothesis testing stage are in line with the results of Indrawan's research (2018) which found that recommendation factors did not significantly influence learning outcomes. In the study of Ratna and Dwiyanti (2016) stated the recommendation factor is often used as a reason for 
a student in choosing an accounting department but the decision was not made by considering selfability as a result when the evaluation process is weak the ability of students in accounting to encourage recommendations does not affect student learning outcomes in studying subjects related to accounting.

At the stage of statistical testing it is also seen that the promotion factor has a path coefficient of 0.148 . This value is strengthened by a probability value of 0.460 . The process of statistical testing is done using an error rate of 0.05 . The results obtained show that the probability value of 0.460 is above the error level of 0.05 , the decision is Ho accepted and Ha rejected or it can be concluded that the professional factor variable (FPR) does not affect the student learning outcomes (HS) accounting department at SMKN 3 Padang.

\section{Conclusion}

The results of the first hypothesis testing personal factors significantly influence the learning behavior of students majoring in accounting at SMKN 3 Padang. The results of testing the second hypothesis of recommendation factors have a positive and significant effect on the learning behavior of accounting department students at SMKN 3 Padang while the results of testing the third hypothesis found career factors have a positive and significant effect on students' learning behavior in accounting at SMKN 3 Padang.

The results of testing the fourth hypothesis of personal factors did not significantly influence the learning outcomes of students majoring in accounting at SMKN 3 Padang. The results of testing the fifth hypothesis The recommendation factor has a positive and significant effect on the learning outcomes of accounting majors at SMKN 3 Padang in contrast to the sixth hypothesis which found that professional factors did not significantly influence student learning outcomes in accounting at SMKN 3 Padang while learning behavior had a significant effect towards student learning outcomes of accounting majors at SMKN 3 Padang.

\section{Suggestion}

In accordance with the conclusions of the results of the hypothesis testing that has been done, it can be proposed some important suggestions that can be useful

1. Students are advised to continually improve their learning behavior by increasing the portion of learning and in conducting material learning activities that are studied not only by theory but also by accounting practices or accounting exercises, so that when students are faced with various accounting problems specifically related to Student accounting practices can better reduce the exam material which will certainly encourage better learning outcomes.

2. Students are advised to also add insights or other references related to the field of accounting, considering the development of the world of accounting, especially in the industrial revolution era 4.0 is increasingly rapid, especially relating to the use of online-based digital technology, in addition students must also regularly consult with teachers, provide time for group learning, it is important to encourage increased student learning outcomes, especially those related to subjects in the field of accounting.

3. Researchers in the future are expected to add other variables that can also influence student learning outcomes such as learning motivation, learning method, and learning model. These suggestions are important to improve the accuracy and accuracy of research results obtained in the past.

\section{References}

Adriana Padma dan Baridwan Zaki. (2016). Faktor Individu dan Faktor Siuasional Determinan Pembuatan Keputusan Etis Konsultan Pajak. Jurnal Ekonomi dan Sosial, 5(2). 
Angraini Dwi Wilda. (2016). Analisis Faktor Faktor yang Mempengaruhi Hasil Belajar Mata Pelajaran Ekononi Kelas XI IIS SMA. E-Jurnal Program Studi Pendidikan Ekonomi Jurusan Pendidikan Ilmu Sosial Fakultas Keguruan dan Ilmu Pendidikan Tanjungpura, Pontianak.

Ghozali Imam. (2011). Analisis Multivariate dengan Menggunakan AMOS 22. Semarang: Badan Penerbit Universitas Diponegoro.

Gibson L James, John M Ivancevic, James H Donelly dan Robert Konopaske. (2009). Organizations Behavior Structure and Processes. McGraw-Hill, Irwin.

Ginting Cipta. (2005). Kiat Belajar di Perguruan Tinggi. Jakarta. Gasindo.

Golemen, Daniel. (2005). Working With Emotional Intelligence. (Terjemahan Alex Tri Kancono Widodo), Jakarta: Gramedia.

Hamalik, Oemar. (2011). Proses Belajar Mengajar. Jakarta: Bumi Aksara.

Harahap Fadli, Raja Adri Setiawan S dan Rheny Afriana Hanif. (2016). Analisis Faktor Faktor yang Mempengaruhi Keputusan Mahasiswa Memilih Jurusan Akuntansi Sebagai Tempat Kuliah di Universitas di Kota Pekanbaru. JOM FEKON 2(2).

Hair Joseph F, William C Black, Barry J Babin, Rolp E Anderson. (2010). Multivariate Data Analysis Data Analisys. Pearson. Prentice-Hall.

Howes dan Herald. (1999). (online) Mengenal Kecerdasan Emosi Remaja. (http//www.e.psikologi.com.remaja/250402.htm).

Hayurika Turina Lasriza dan Arief. (2015). Analisis Faktor Faktor yang Mempengaruhi Minat Siswa Dalam Pengambilan Keputusan Memilih Jurusan Akuntansi Kelas X di SMK N 1 Demak. Jurnal Pendidikan Ekonomi Dinamika Pendidikan, X(1), 88 - 103

Sebagai Tempat Kuliah di Perguruan Tinggi. Jakarta: Artikel Ilmu Pendidikan Akuntansi Fakultas Ekonomi Universitas Budi Luhur.

Melandy, Rissyo dan Nurna Aziza. (2006). "Pengaruh Kecerdasan Emosional terhadap Tingkat Pemahaman Akuntansi, Kepercayaan Diri sebagai Variabel Pemoderasi". Simposium Nasional Akuntansi 9 Padang.

Mulyani Sri, Sausan Inas dan Utami Budi. (2016). Faktor Faktor yang Berpengaruh Terhadap Prestasi Belajar Siswa Pada Pokok Bahasan Konsep Mol. Jurnal Penelitian Pendidikan, 19(1).

Rahayu Sri dan Rusmawan R Wedi. (2010). Analisis Faktor Faktor yang Mempengaruhi Minat Untuk Mengikuti Program Pendidikan Profesi Akuntansi (PPAk) (Survey Pada Mahasiswa dan Alumni Program Akuntansi S1 Universitas X Bandung). Purwokerto: SNA XIII Universitas Jendral Sudirman.

Rusno. (2016). Faktor Faktor yang Mempengaruhi Keefektifan Mahasiswa Dalam Proses Pemebelajaran Mahasiswa Program Studi Akuntansi Universitas Kanjuruhan Malang Tahun 2011. Jurnal Inspirasi Pendidikan Universitas Kanjuruhan Malang.

Sari Amelga Mela, Hewati, dan Dandes Rifa. (2016). Pengaruh Faktor Personal, Culture, Pshycological dan Citra Perguruan Tinggi Terhadap Keputusan Memilih Jurusan Akuntansi (Studi Empiris Mahasiswa Akuntansi di Kota Padang). E-Jurnal Jurusan Akuntansi Fakultas Ekonomi Universitas Bung Hatta, Padang.

Siagian, Sondang P. (2010). Manajemen Sumber Daya Manusia. Jakarta: Bumi Aksara

Slameto. (2010). Belajar dan Faktor yang Mempengaruhinya. Jakarta: Rineka Cipta.

Stern J Norman Altekruse, Sean F., Patricia I. Fields., and David L. Swerdlow. (1999). Campylobacter Jejuni-An Emerging Foodborne Pathogen" Emerging Infectious Diseases, 5(1)

Suryati P, dan Ika N P. (2004). Pengaruh Kecerdasan Emosional Terhadap Pemahaman Akuntansi. Jurnal Ekonomi dan Bisnis. 